Jpn. J. Genet. (1989) 64, pp. 209-222

\title{
Karyotype evolution in the social wasps (Hymenoptera, Vespidae)
}

\author{
Hidehiro HoshiBa*, Makoto MatsuUra** \\ and Hirotami T. IMAI*** \\ *Daito Bunka University, Dai-Ichi High School, \\ Takashimadaira, Itabashi, Tokyo 175 \\ **Mie University, Tsu, Mie-ken 514 \\ ${ }^{* * *}$ National Institute of Genetics, Mishima, Shizuoka-ken 411
}

(Received 9 February 1989)

\begin{abstract}
The chromosomes of 21 species of Vespidae (consisting of 9 polistines and 12 vespines) were compared using an air-drying technique. The haploid number of the Polistinae ranged broadly $(n=14,22,23,26,30,31$, and 34$)$, while it was either $n=25$ or $n=26$ in the Vespinae. There were no karyological homologies (in terms of marker chromosomes) between these two subfamilies. Some phylogenetic relationships of social wasps were discussed, based on the karyological literature now available (32 species). We suggested that the three genera of Vespinae (Dolichovespula, Vespa, and Vespula) would have differentiated in two different ways from a common ancestor having 27 acrocentrics $(n=27)$ by tandem fusion (the first genus with $n=26$ ) and by two centric fusions (the latter two genera with $\mathrm{n}=25$ ). In the genus Polistes, the 5 subgenera (Fuscopolistes, Aphanilopterus, Megapolistes, Polistella, and Polistes) would have evolved independently toward increasing chromosome numbers since they started to separate from their ancestor having $n=9-14$.
\end{abstract}

\section{INTRODUCTION}

The cytology of hymenopterans, especially of ants and sawflies, has been flourishing since the improvement of the chromosome observation technique, the so-called air-drying technique (Imai et al., 1977, 1984, 1988a; Naito, 1978a, b, 1982; for a general outline see Crozier, 1975).

In spite of such an advance in hymenopteran cytology, chromosome observations of the social wasps (Vespidae) have rarely been made. For example, before 1975, chromosome numbers of only 5 polistine species were known, i.e., Polistes rothneyi $(\mathrm{n}=6), \mathrm{P}$. jadwigae $(\mathrm{n}=9), P$. snelleni $(\mathrm{n}=13), P$. omissis $(\mathrm{n}=14)$ and $P$. gallicus $(\mathrm{n}=21)$ (Machida, 1934; Pardi, 1947). These data suggest varistion in chromosome number among the social wasps, although a re-examination of data by modern techniques is needed.

In this connection, one of us ( $H$. H.) and his co-workers have attempted recently to apply an air-drying technique for the chromosomal observation of a 
social wasp ( $P$. snelleni), and revealed that the species has actually $\mathrm{n}=30$ (Hoshiba and Ono, 1984). They listed in their paper the chromosome numbers of 12 social wasps, which ranged from $n=9,14,16,19,21,22,25,26,28,31$, to 33 . As will be discussed later, the average chromosome number $(\bar{n})$ of the social wasps $(\bar{n}=25.3)$ seems to be noticeably higher than that found in sawflies $(\bar{n}=9.9)$ and rather comparable with ants having higher chromosome numbers $(n>12)$. These data suggest that further accumulation of karyological data of the social wasps might be valuable for discussing the karyotype evolution of hymenopterans, which is addressed in the present paper.

\section{MATERIALS AND METHODS}

Chromosomes were studied in 21 social wasp species belonging to two subfamilies; Polistinae (one species of Parapolybia, 8 species of Polistes) and Vespinae (7 species of Vespa, 3 species of Vespula, and 2 species of Dolichovespula) (Table 1).

These wasps were collected from Japan, England, Federal Republic of Ger-

Table 1. The haploid chromosome number of Vespidae

\begin{tabular}{|c|c|c|c|c|c|c|c|}
\hline $\begin{array}{l}\text { Genus } \\
\text { (Subgenus) }\end{array}$ & Species & $\underset{n}{\text { Chrom. }}$ & $\begin{array}{l}\text { no. } \\
2 \mathrm{n}\end{array}$ & $\begin{array}{l}\text { Locality } \\
\text { code }\end{array}$ & $\begin{array}{l}\text { Cell no. } \\
\text { obs. }\end{array}$ & Fig. & References* \\
\hline \multicolumn{8}{|c|}{ Subfamily POLISTINAE } \\
\hline Parapolybia & indica & 14 & - & $\operatorname{MT}(2)$ & 16 & $1 a$ & 7, Present paper \\
\hline Polistes & carolina & 19 & & & & & 1 \\
\hline \multirow[t]{3}{*}{ (Fuscopolistes) } & apachus & 22 or 25 & & & & & 1 \\
\hline & fuscatus & 26 & & & & & 2 \\
\hline & metricus & 26 & & & & & 1. \\
\hline \multirow{4}{*}{$\begin{array}{l}\text { (Aphanilo- } \\
\text { pterus) }\end{array}$} & canadensis & 16 & & & & & 3 \\
\hline & similimus & 28 & & & & & 4 \\
\hline & versicolor & 31 & & & & & 4 \\
\hline & exclamans & 33 & & & & & 1 \\
\hline \multirow[t]{4}{*}{ (Megapolistes) } & hebraeus & 9 & & & & & 5 \\
\hline & rothneyi iwatai & 31 & 62 & TT;US(2) & 39 & $1 b$ & Present paper \\
\hline & rothneyi ingrami & 31 & - & NO & 7 & - & Present paper \\
\hline & jadwigae & 31 & 一 & TM(2);US & 62 & 1c & Present paper \\
\hline \multirow[t]{3}{*}{ (Polistella) } & mandarinus & 26 & 52 & $\mathrm{HT}$ & 32 & Id & Present paper \\
\hline & snelleni & 30 & 60 & $\operatorname{IT}(1) ; \operatorname{TOS}$ & 60 & le & 8 , Present paper \\
\hline & japonicus & 34 & - & $\mathrm{TM}(2)$ & 35 & If & Present paper \\
\hline \multirow[t]{5}{*}{ (Polistes) } & omissus & 14 & & & & & 6 \\
\hline & gallicus & 21 & & & & & 6 \\
\hline & nyumpha & 22 & - & PP & 26 & $2 a$ & Present paper \\
\hline & riparius & 22 & - & SH & 26 & $2 \mathrm{~b}$ & Present paper \\
\hline & chinensis & 23 & - & US(1);IT & 21 & $2 c$ & Present paper \\
\hline
\end{tabular}


Table 1. The haploid chromosome number of Vespidae (continued)

\begin{tabular}{|c|c|c|c|c|c|c|c|}
\hline $\begin{array}{l}\text { Genus } \\
\text { (Subgenus) }\end{array}$ & Species & $\underset{\mathrm{n}}{\text { Chrom. }}$ & $\begin{array}{l}\text { no. } \\
2 \mathrm{n}\end{array}$ & $\begin{array}{l}\text { Locality } \\
\text { code }\end{array}$ & $\begin{array}{l}\text { Cell no. } \\
\text { obs. }\end{array}$ & Fig. & References* \\
\hline \multicolumn{8}{|c|}{ Subfamily VESPINAE } \\
\hline \multirow[t]{7}{*}{ Vespa } & $\begin{array}{l}\text { mandarinia } \\
\text { simillima }\end{array}$ & 25 & - & MT(2) & 31 & $3 a$ & 9, Present paper \\
\hline & xanthoptera & 25 & - & $\operatorname{MT}(2)$ & 23 & $\mathbf{3 b}$ & 9, Present paper \\
\hline & crabro & 25 & 50 & TAS;OWG & 60 & $3 \mathbf{c}$ & Present paper \\
\hline & dybowskii & 25 & - & $\mathrm{MT}(3)$ & 17 & 3d & Present paper \\
\hline & affinis & 25 & - & KUT;UPM & 13 & $3 \mathrm{e}$ & Present paper \\
\hline & analis & 25 & 50 & MT(2);TM(1) & & & Present paper \\
\hline & tropica & 25 & 50 & TM(1);MS & 29 & $3 g$ & Present peper \\
\hline \multirow[t]{3}{*}{ Vespula } & flaviceps & 25 & 50 & UT(1);UT(2) & 33 & $4 a$ & 9, Present paper \\
\hline & shidai & 25 & 50 & $\mathrm{UT}(2)$ & 30 & $4 b$ & Present paper \\
\hline & vulgaris & 25 & - & LE;OWG & 32 & $4 \mathrm{c}$ & Present paper \\
\hline \multirow[t]{2}{*}{ Dolichovespula } & sylvestris & 26 & - & LE;OWG & 14 & $4 d$ & Present paper \\
\hline & saxonica & 26 & - & OWG;WP & 13 & $4 e$ & Present paper \\
\hline
\end{tabular}

*Numbers reffer to cited literature: 1 , Hung et al. (1981); 2, Goodpasture (1974), quoted from Hung et al. (1981); 3, Kerr (1952); 4, Pompolo \& Takahasi (1986); 5, Mizura \& Slivastava (1972); 6, Pardi (1947); 7, Hoshiba (1985); 8, Hoshiba \& Ono (1984); 9, Hoshiba \& Yamamoto (1985).

many, Poland, Malaysia, and Thailand, during the years from 1983 to 1986 (Table 2). The samples from Asia were identified by Matsuura, while the European species were identified by R. Edwards (England), N. Koeniger (Federal Republic of Germany), and M. Bilinski (Poland). The dry or alcohol specimens of these wasps were preserved by Hoshiba.

The chromosomal preparations were made following the air-drying technique of Imai et al. (1984) with slight modifications. A brief outline is as follows:

We used the testes or ovaries of young larvae (3rd or 4th instar), and also the brains of prepupae, if available. These organs were taken out in a hypotonic solution $(0.4 \% \mathrm{KCl}$ with $0.01 \%$ colchicine), and were treated in a fresh hypotonic solution at room temperature for 30 minutes. We used a drop of diluted lactic acid (one part of $30 \%$ lactic acid in acetic acid; two parts of $60 \%$ acetic ethanol) for macerating the organs by dissecting needles. The preparations were stained with a freshly prepared Giemsa solution. For the details of the technique, see Imai et al. (1988a).

\section{RESULTS}

The results of our chromosome counts are summarized in Table 1. In addition, some karyological characteristics of each genus or subgenus will be given here. 
Table 2. Localities where the social Vespidae used in the present study were collected

\begin{tabular}{ll}
\hline Code & Locality, year \\
\hline HT & Hinoharu, Tokyo, 1986 \\
IT & Itabashi, Tokyo, 1986 \\
KUT & Kasetzart University, Thailand, 1986 \\
LE & Lingfield, England, 1985 \\
MS & Mishima, Shizuoka, 1986 \\
MT(1) & Machida, Tokyo, 1983 \\
MT(2) & Machida, Tokyo, 1984 \\
MT(3) & Machida, Tokyo, 1985 \\
NO & Naha, Okinawa, 1986 \\
OWG & Oberursel, West Germany, 1985 \\
PP & Pulawy, Poland, 1985 \\
SH & Sapporo, Hokkaido, 1986 \\
TAS & Takasaka, Saitama, 1986 \\
TM(1) & Tsu, Mie, 1985 \\
TM(2) & Tsu, Mie, 1986 \\
TOS & Tokorozawa, Saitama, 1986 \\
TT & Tanashi, Tokyo, 1986 \\
UPM & University Pertanian Malaysia, 1986 \\
US & Urawa, Saitama, 1986 \\
UT(1) & Utsunomiya, Tochigi, 1985 \\
UT(2) & Utsunomiya, Tochigi, 1986 \\
WP & Warsaw, Poland, 1985 \\
\hline
\end{tabular}

Note: Each code shows both the locality and the year collected. The numbers in parentheses indicate the different collection years at the same locality.

\section{1) POLISTINAE}

\section{Genus Parapolybia}

Fig. 1a shows the chromosomes of $P$. indica. All chromosomes were meta- or submetacentric and roughly equal in size.

\section{Genus Polistes}

Subgenus Megapolistes: Many years ago, Machida (1934) reported the chromosome numbers of $P$. rothneyi and $P$. jadwigae to be $n=6$ and 9 , respectively. However, our present observations revealed that the chromosomes of the two species have $n=31$. Their karyotypes show metacentric rich in conventional chromosomal nomenclature (Figs. $1 \mathrm{~b}$ and 1c), but some of them may be pseudoacrocentrics ( $\mathrm{A}^{\mathrm{M}}$ : acrocentrics having extraordinarily elongated C-band positive short arms (Imai et al., 1988a)). The two subspecies of $P$. rothneyi, $P . r$. iwatai and $P$. r. ingrami are karyologically identical; the karyotype of $P . r$. iwatai is 


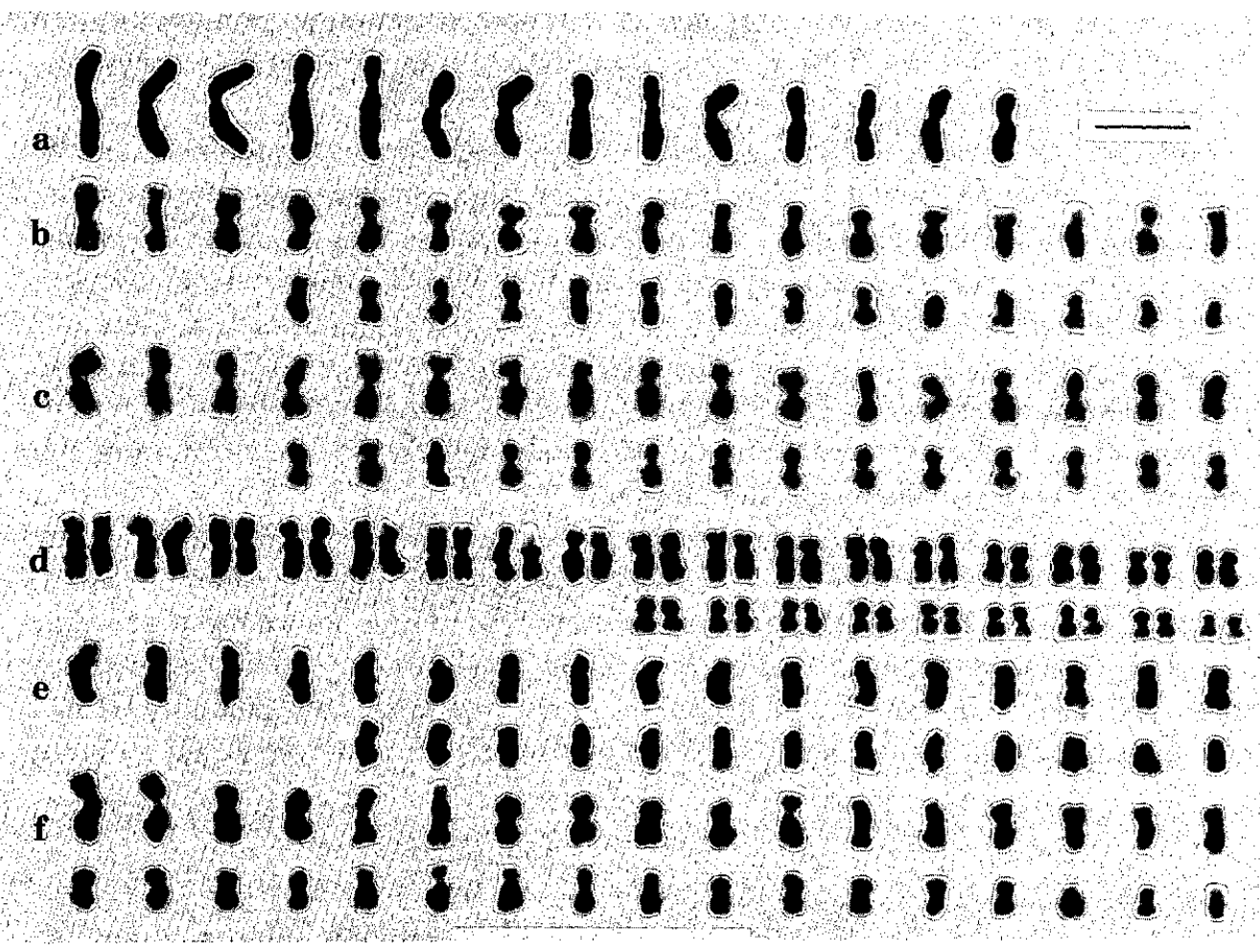

Fig. 1. Karyotypes of polistine wasps (I). a, Parapolybia indica $(n=14) ; b$, Polistes (Megapolistes) rothneyi iwatai $(\mathrm{n}=31) ; \mathrm{c}, P$. (M). jadwigae $(\mathrm{n}=31) ; \mathrm{d}, P$. (Polistella) mandarinus $(\mathrm{n}=26) ; \mathrm{e}, P$. (P.) snelleni $(\mathrm{n}=30) ; \mathrm{f}, P$. $(P)$ japonicus $(\mathrm{n}=34)$. The bar indicates $5 \mu \mathrm{m}$.

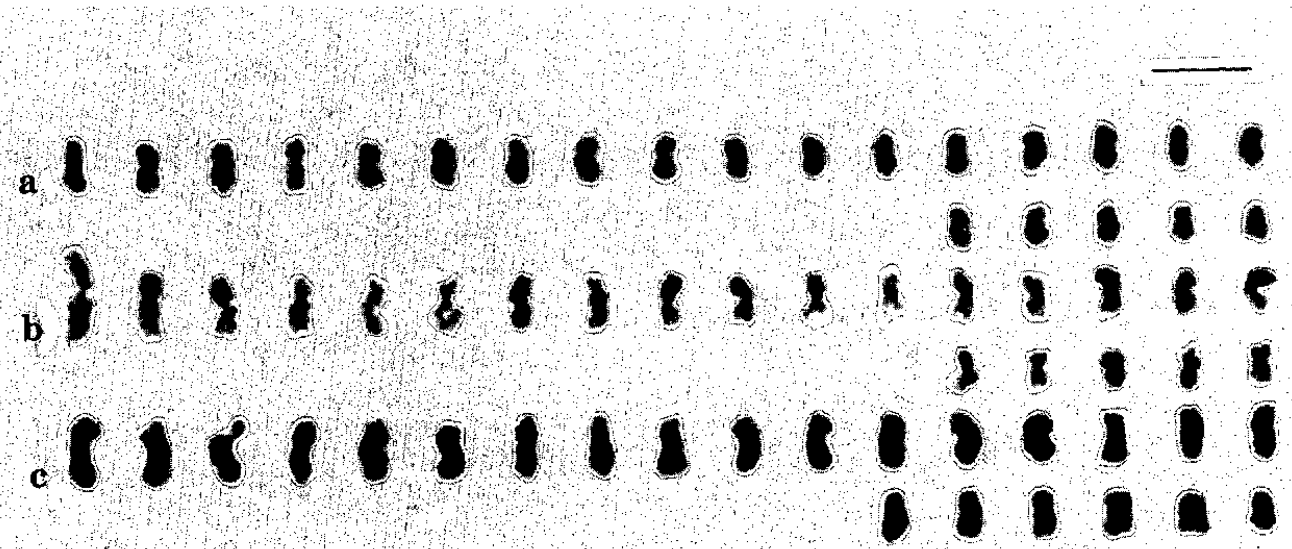

Fig. 2. Karyotypes of polistine wasps (II). a, Polistes (Polistes) nympha $(\mathrm{n}=22) ; \mathrm{b}, P$. (P.) riparius $(\mathrm{n}=22) ; \mathrm{c}, P$. $(P$.$) chinensis (\mathrm{n}=23)$. The bar indicates $5 \mu \mathrm{m}$. 
represented in Fig. 1b. We obtained $P$. r. iwatai from the two localities of Tanashi (TT) and Urawa (US), though there were no morphological or karyological differences between them.

Subgenus Polistella: Three species, $P$. mandarinus, $P$. snelleni, and $P$. japonicus, were examined. They have rather high chromosome numbers, i.e., $\mathrm{n}=26,30$, and 34 , respectively. Note that $P$. japonicus has the highest chromosome number of the vespine wasps so far studied. Each species shows meta- or submetacentric rich karyotypes (Figs. 1d, 1e, and 1f), though most of them may be in fact pseudo-acrocentrics ( $\mathrm{A}^{\mathrm{M}}$ ) as suggested in Megapolistes (Figs. $1 \mathrm{~b}$ and $1 \mathrm{c}$ ). For $P$. snelleni, Machida (1934) reported $n=13$, but recently Hoshiba and Ono (1984) found $n=30$ in the male and $2 n=60$ in the female. We confirm here that the species certainly has $n=30$ and $2 n=60$.

Subgenus Polistes: The chromosomes of three species, $P$. nympha, $P$. riparius, and $P$. chinensis were observed (Figs. 2a, 2b and 2c). $P$. nympha and $P$. riparius have $\mathrm{n}=22$, and $P$. chinensis has $\mathrm{n}=23$. These karyotypes are characterized by the predominance of meta- or submetacentrics. $P$. riparius was first described as $P$. opinabilis (a synonym of $P$. nympha) by Ishikawa (1965). However, taxonomists did not accept his nomenclature, and often used $P$. biglu-

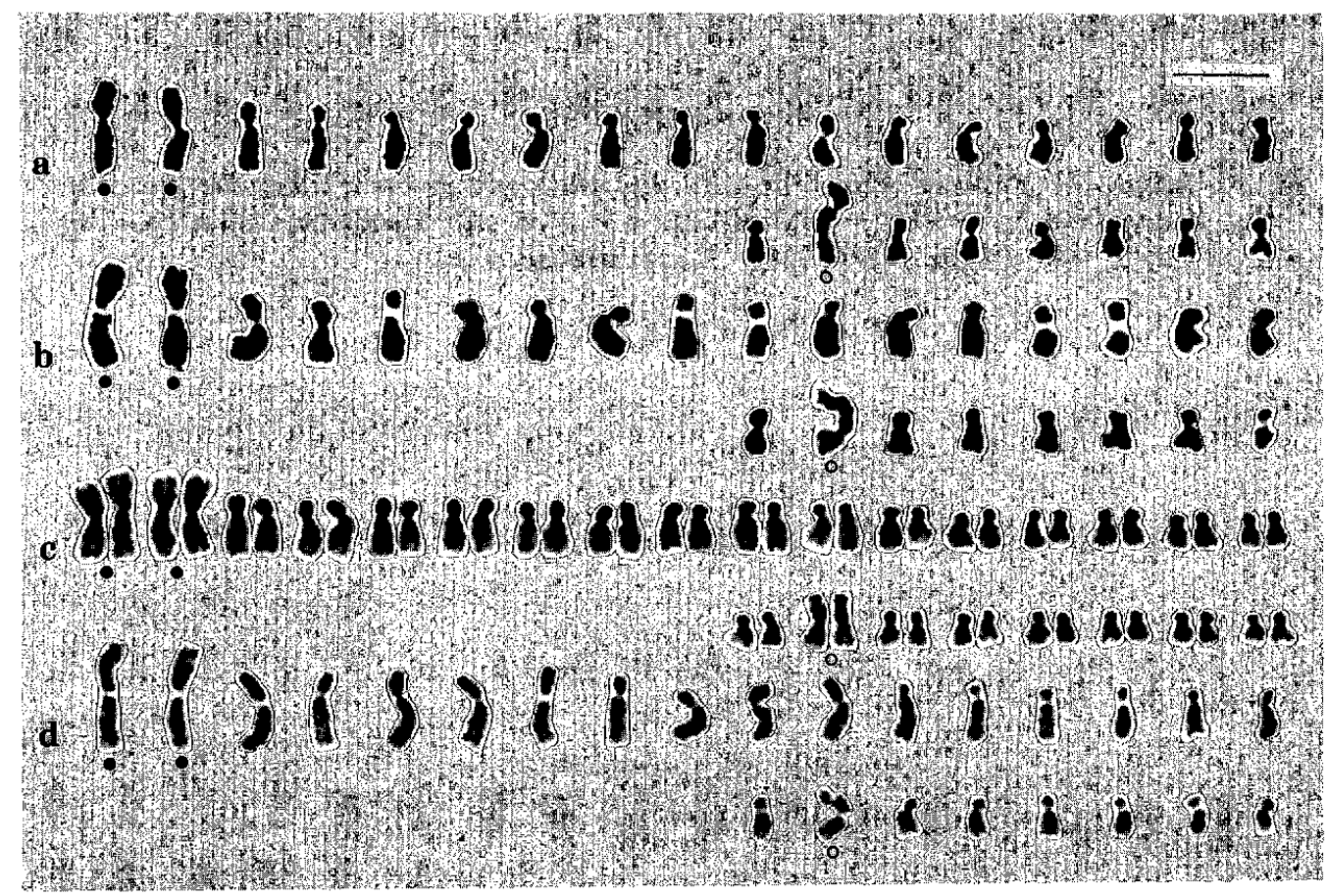

Fig. 3. Karyotypes of vaspine wasps (I). a, Vespa mandarinia $(\mathrm{n}=25) ; \mathrm{b}, \mathrm{V}$. simillima xanthoptera $(\mathrm{n}=25)$; c, V. crabro $(\mathrm{n}=25) ; \mathrm{d}, V$. dybowskii $(\mathrm{n}=25)$. Solid and open circles are marker chromosomes. The bar indicates $5 \mu \mathrm{m}$. 
mis (Yamane, 1969) instead. Quite recently, Yamane and Yamane (1987) concluded that this wasp, being close to $P$. nympha, is an independent new species, $P$. riparius. We found that the two species are karyotypically different, because $P$. riparius has one large metacentric (M) (Fig. $2 b$ ) whereas there is no such marker $\mathrm{M}$ in $P$. nympha (Fig. 2a).

\section{2) VESPINAE}

\section{Genus Vespa}

All of the seven vespa species examined showd the same haploid chromosome number $n=25$. They are karyologically very conservative, i.e., they have three large marker chromosomes (Figs. 3 and 4; solid and open circles), two of which are metacentric and the third of which is $\mathrm{A}^{\mathrm{M}}$ accompanied by a conspicuous secondary constriction. The remaining small components look like meta- or submetacentrics (c.f. Hoshiba and Yamamoto, 1985). The C-banded karyotype of V. crabro suggests, however, that they are principally acrocentrics or $A^{M_{S}}$ (Fig. 3c). Note that C-banded karyotypes are obtained without any special treatments by using the air-drying method improved by Imai et al. (1988a).

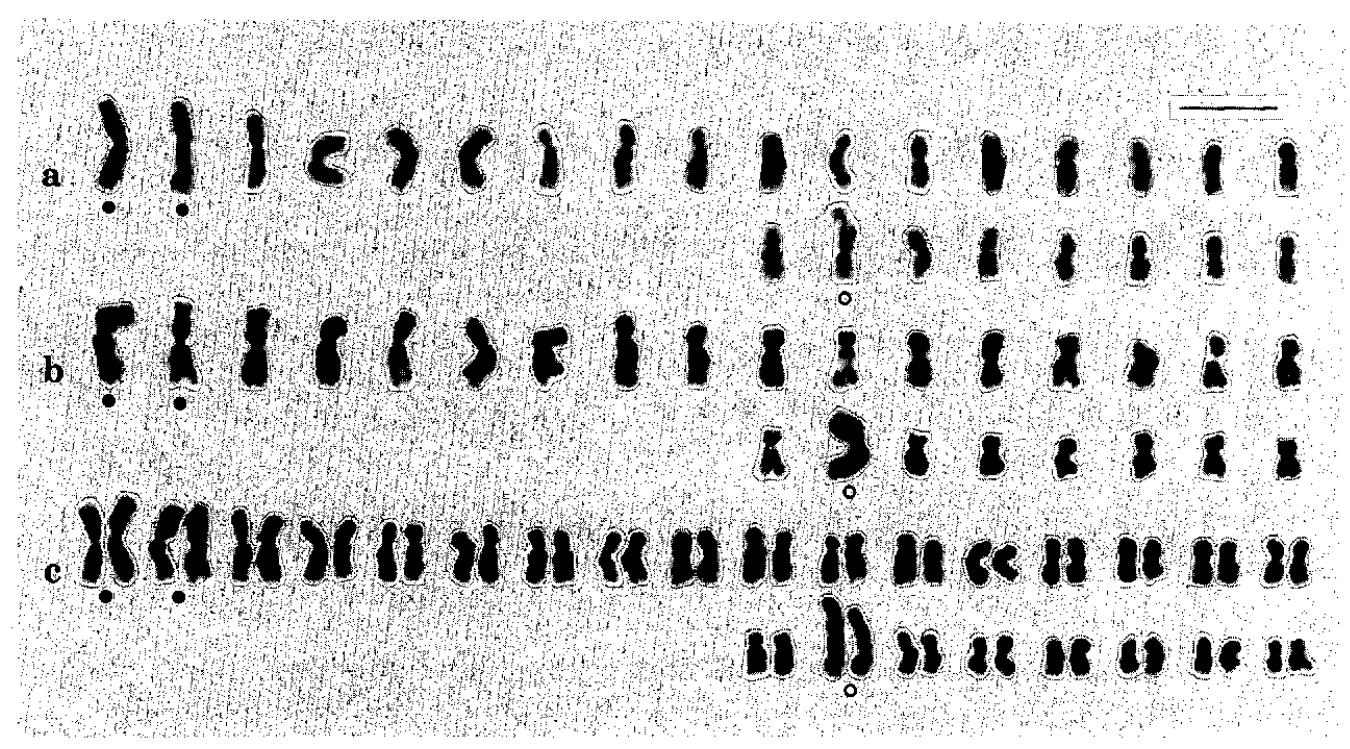

Fig. 4. Karyotypes of vespine wasps (II). a, Vespa affinis $(n=25) ; b, V$. analis $(n=25) ; c, V$. tropica $(n=25)$. Solid and open circles are marker chromosomes. The bar indicates $5 \mu \mathrm{m}$.

Although these species are divided into two groups by Matsuura and Yamane (1984), i.e., temperate zone species (V. mandarinia, V. simillima, $V$. crabro and $V$. dybowskii) and tropical zone species (V. affinis, V. analis and $V$. tropica), our present observations revealed no distinctive karyological differences between them. 


\section{Genus Vespula}

We karyotyped 3 Vespula species, Vl. (Paravespula) flaviceps, vl. (P.) shidai, and $V l .(P)$ vulgaris (Figs. 5a, 5b, and 5c, respectively). Although $V l$. flaviceps and $V l$. vulgaris were collected from four widely separated localities (see Table 2), no karyological differences were detected between the localities.

We conclude that the haploid $(n=25)$ karyotypes are basically composed of 2 large metacentrics and 23 ordinary type acrocentrics. As the marker $\mathrm{Ms}$ have C-bands at the proximal regions of both arms (Fig. $5 \mathrm{f}$ ), they may be induced by centric fusion (or more precisely telomere fusion) as suggested by Imai et al. (1988b). These acrocentrics are quite distinguishable from the pseudoacrocentrices $\left(\mathrm{A}^{\mathrm{M}}\right)$ of Vespa. However, Vespula and Vespa share the two large marker metacentrics suggesting a phylogenetical relationship between them (compare Figs. 3, 4, and 5).

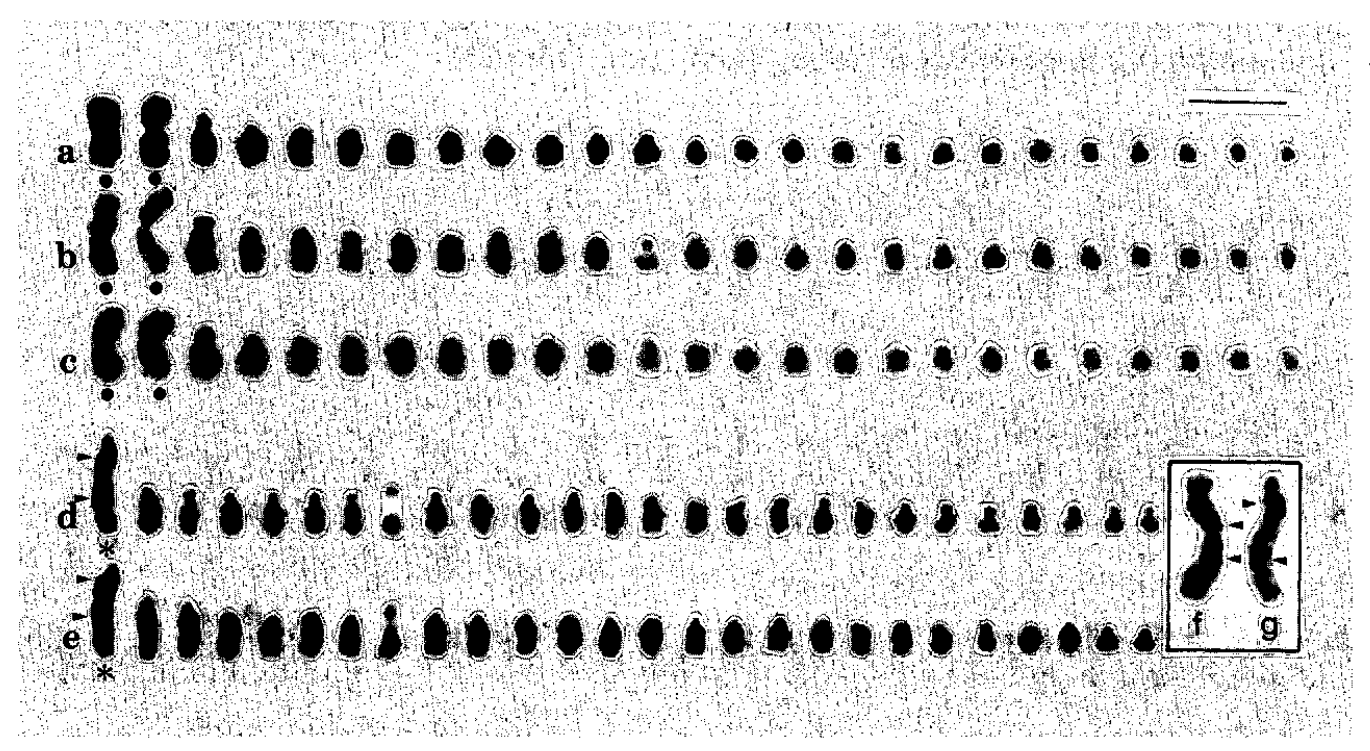

Fig. 5. Karyotypes of vespine wasps (III). a, Vespula (Paravespula) flaviceps (n=25); b, Vl. (P.) shidai $(\mathrm{n}=25) ; \mathrm{c}, V l$. (P.) vulgaris $(\mathrm{n}=25) ; \mathrm{d}$, Dolichovespula (Metavespula) sylvestris $(\mathrm{n}=26) ; \mathrm{e}, D$. (Boreovespula) saxonica $(\mathrm{n}=26)$. Solid circles and asterisks are marker $M$ and $A$ chromosomes, respectively. Inset: (f) marker $M$ of $V$. s. xanthoptera, and (g) marker $A$ of $D$. sylvestris. Arrow heads mean $\mathrm{C}$-bands detected. The bar indicates $5 \mu \mathrm{m}$.

\section{Genus Dolichovespula}

Two species, $D$. (Metavespula) sylvestris and $D$. (Boreovespula) saxonica have $\mathrm{n}=26$, and all chromosomes are acrocentrics (Figs. 5d and 5e). Chromosome No. 1 of each species was a noticeably large acrocentric with interstitial C-bands and a 
faint constriction (Figs. 5d, 5e, and 5g). Karyotypes of both species were compared with the material from plural localities $(D$. sylvestris from LE and OWG, and $D$. saxonica from $O W G$ and WP), but no variations were found. This genus is karyologically very similar to Vespula (Figs. 5a and 5b), as they both have ordinary type acrocentries. However, there is a distinctive karyological gap in that they do not share the two large marker metacentrics.

\section{DISCUSSION}

1) Chromosomal differentiation in social wasps with reference to the karyotype evolution of hymenopterans

Altogether, chromosomal data on 32 social wasp species are now available. They range broadly from $n=9$ to 34 , and the mean vaule is $\bar{n}=25.3$. The number of species examined cytologically is only about $4 \%$ of known social wasps, and some pioneer works (Machida, 1934; Pardi, 1947; Kerr, 1952) probably need to be reexamined. However, it is a noteworthy characteristic that they have rather high numbers of chromosomes compared to other hymenopterans, such as sawflies and some ants. According to Naito (1982), the majority of sawflies have chromosome numbers lower than $\mathrm{n}=10$ (Fig. 6a). On the other hand, the mean number of ant chromosomes is $\bar{n}=15.7$, although we need discuss ants in greater detail.

Recently accumulated data on ant chromosomes (More than 500 species) have revealed that this group is chromosomally highly diversified, ranging from $\mathrm{n}=1$ up to $\mathrm{n}=42$ (Fig. 6b) (for details see Crozier, 1975; Imai et al., 1977, 1984). Imai et al. (1988a) divided ants into two groups, (1) species having low numbers of chromosomes $(n \leqq 12)$ and (2) species with high numbers $(n>12)$, based on the cytological evidence that translocation polymorphisms appear preferentially in the former, while Robertsonian polymorphisms predominate in the latter. If this classification system is applicable to hymenopterans in general, then our social wasps fall into the second category of species (Fig. 6c), and the sawflies mentioned above are comparable to species having low-numbers (Fig. 6).

Imai et al. (1986, 1988a, b) proposed a global model for the karyotype evolution of eukaryotes, which is called the Munimum Interaction Hypothesis. This hypothesis implies that karyotypes tend to evolve toward minimizing the genetic risks resulting from deleterious translocations. A brief outline of the hypothesis is as follows: In the interphase nuclei of eukaryotes, chromosomes distribute non-randomly by attaching their terminal ends to the inner surface of the nucleus, which is termed the hammock structure or the suspension arch structure. It was demonstrated by Monte Carlo simulation methods that, under the hammock structure, chromosomal interactions (i.e., exchanges inducing translocations) may increase noticeably in karyotypes with lower chromosome numbers (especially in those with $n \leqq 12$ ). The translocation polymorphisms found in ants with low numbers of chromosomes were considered as supporting evidence for the hypoth- 

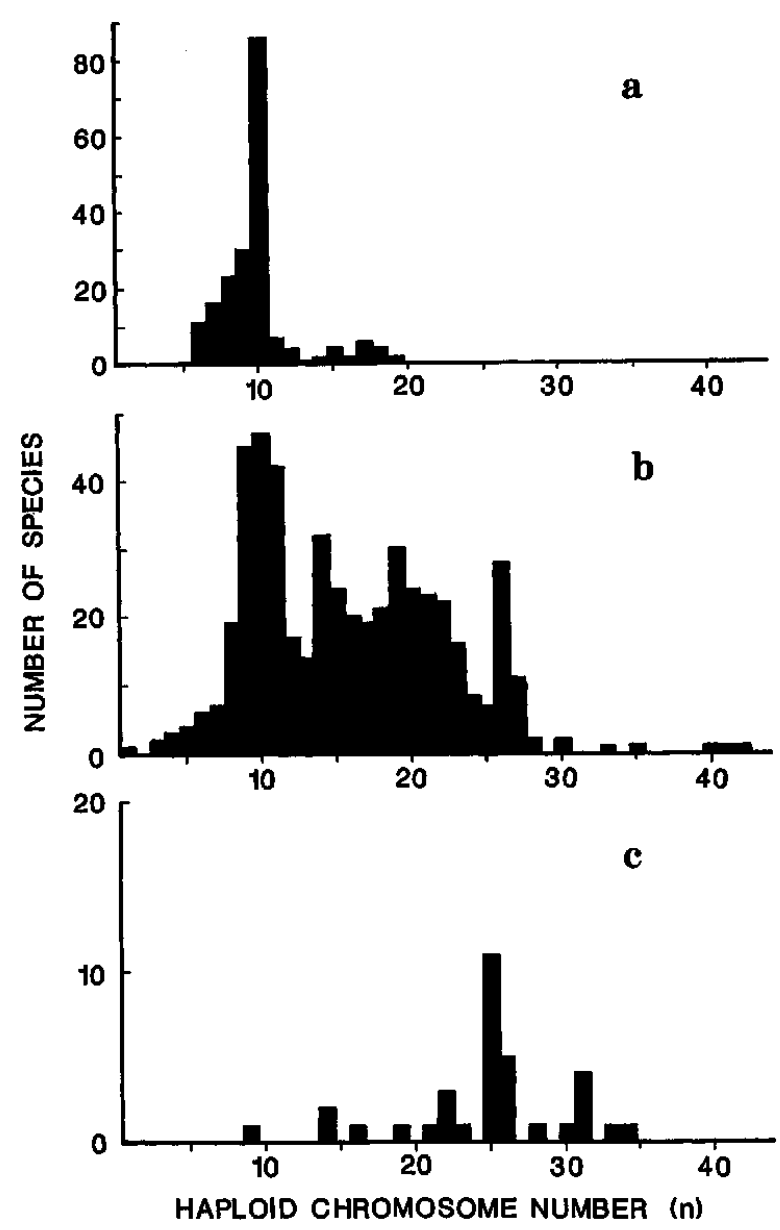

Fig. 6. Frequency distribution of chromosome numbers in Hymenopteran insects. a, sawflies; b, ants; c, social wasps.

esis, and Robertsonian polymorphisms, which are charateristic in ants having high numbers of chromosomes, were considered to be highly effective in minimizing the risks related to translocation, if chromosome numbers increase by centric fission. The minimum interaction hypothesis is consistent with the so-called fission hypothesis, which was promoted mainly for mammals by Imai $(1975,1978)$, Imai and Maruyama (1978), and Imai and Crozier (1980).

Now, we attempt to interpret the chromosome number variations found in sawflies (Fig. 6a), ants (Fig. 6b), and social wasps (Fig. 6c) in terms of the fission hypothesis, which was supported by the minimum interaction hypothesis. In the fission hypothesis, karyothpes tend as a whole to evolve toward increasing chromosome numbers and/or arm numbers mainly by centric fission and a pericentric inversion, termed $A \bar{M}$ inversion. We emphasize that centric fusion 
(i.e., the alternative rerrangement to centric fission) can contribute in the fission hypothesis as a transient phase or as a local back eddy in the main stream by centric fission and $A \bar{M}$ inversion (for details, see Imai et al., 1988a, b). Taking this information into account, the most likely interpretation for hymenopteran karyotype evolution may be to assume that ancestral hymenopterans would have had rather low chromosome numbers $(n \leqq 12)$, and thus they might have had the problem related to translocation. The majority of the sawflies and the lownumbered ants still remain in such a situation. On the other hand, social wasps and the high-numbered ants have succeeded in escaping from these risks by increasing their chromosome numbers.

\section{2) Chromosomal differentiation of polistine and vespine wasps}

As far as our chromosomal observations are concerned, there are some essential differences in the variation of chromosome numbers between Polistinae and Vespinae. The haploid numbers vary extremely in the former $(n=9-34)$, while they are uniform in the latter $(n=25$ or 26) (Table 1). In the genus Polistes, such a noticeable variation was found in all of the 5 subgenera examined, i.e., $\mathrm{n}=19-26$ in Fuscopolistes, $\mathrm{n}=16-33$ in Aphanilopterus, $\mathrm{n}=9-31$ in Megapolistes, $\mathrm{n}=26-34$ in Polistella, and $\mathrm{n}=14-23$ in Polistes. We could not detect solid karyological homology (in terms of marker chromosomes) among these subgenera (Figs. 1 and 2), suggesting that each lineage would have evolved independently or in parallel, since they started from the common ancestors having $n=9-14$ (Fig. 7).

In contrast to Polistinae, the members of Vespinae are karyologically resemble each other closely (Figs. 3-5). For examples, Vespa and Vespula are characte-

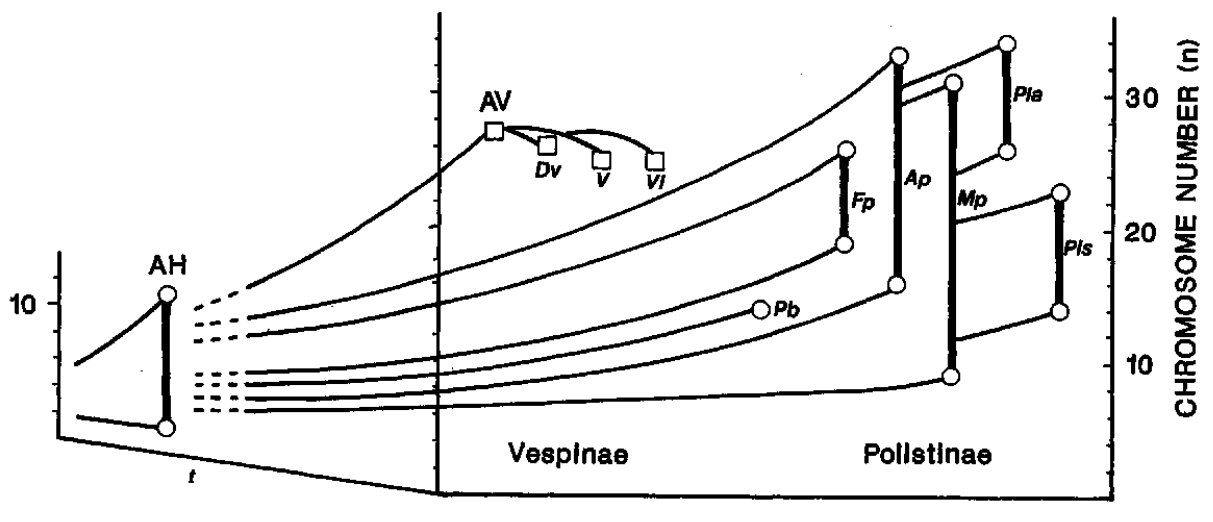

MORPHOLOGICAL DIFFERENTIATION

Fig. 7. A schematic representation of the chromosomal diversification of Vespidae. AH, Ancestral Hymenoptera; AV, Ancestral Vespinae; Ap, Aphanilopterus; Dv, Dolichovespula; Fp, Fuscopolistes; Mp, Megapolistes; Pb, Parapolybia; Pla, Polistella; Pls, Polistes; V, Vespa; Vl, Vespula. 
rized by acrocentric $(A)$ or pseudo-acrocentric $\left(A^{M}\right)$ rich karyotypes, and they share the two large marker metacentrics (2M) (Figs. 3-5, solid circles and also see Fig. 5f, inset) and a pseudo-acrocentric with a remarkable secondary constriction (Figs. 3-5, open circles). The karyotype of Dolichovespula is almost identical to these two vespine genera, except one large acrocentric (Figs. $5 \mathrm{~d}$ and $5 \mathrm{e}$, asterisks). Although it is not clearly shown in Figs. 5d and 5e, the large acrocentric has C-bands at the proximal and interstitial regions of the long arm (Fig. 5g, inset). This karyological evidence suggests that the three genera of Vespinae would have differentiated in two directions from a common ancestor having 27 acrocentrics $(\mathrm{n}=27)$, i.e., one lineage (Dolichovespula; $\mathrm{n}=26$ ) probaly by tandem fusion, and the others (Vespa and Vespula; $\mathrm{n}=25$ ) by two centric fusions (Fig. 7). As there are no homologies (in terms of conventional chromosomal morphologies) between polistinae and Vespinae, these two groups would have evolved independently from their ancestors having low chromosome numbers $(n \leqq 12)$. Although there is some controversy about the origin of the vespine genera, stemming from various morphological and ethological points of view (Yamane, 1976, Greene, 1979, Akre, 1982), our karyological data suggest that Vespa and Vespula are closely connected, and that Dolichovespula seems to conserve the ancestral karyotype of the Vespinae, in distinction to the other two genera (Fig. 8). Further detailed analyses of the karyotype evolution of the social wasps will be provided by improving the C-band technique in future.

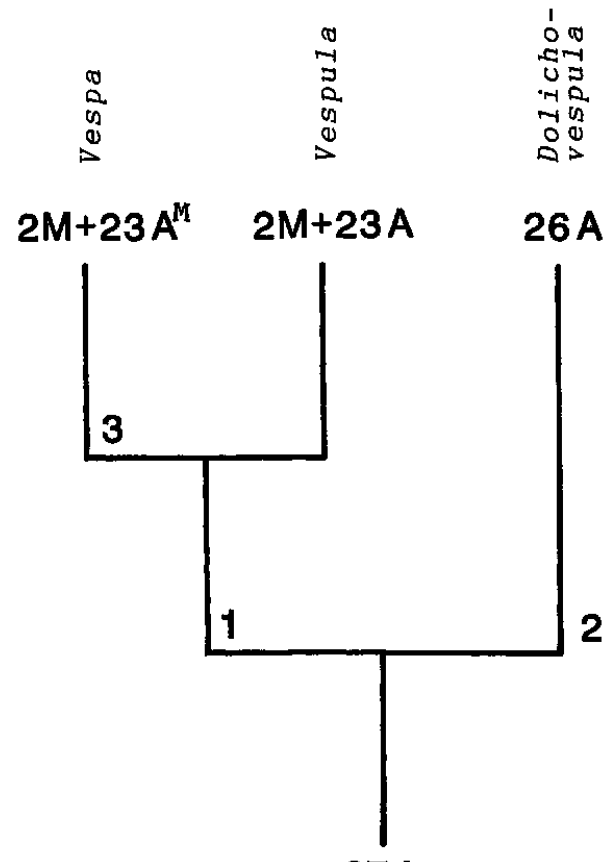

Fig. 8. A possible phylogenical tree based on the karyological homologies among the social vespine wasps.

1: $n=26$, with one large $A$ induced probably by a tandem fusion.

2: $n=25$, with large Ms originated from centric fusions.

3: $n=25$, having many pseudo-acrocentrics $\left(A^{M}\right)$ induced by tandem growth of constitutive heterochromatin (t.g.c.h.). 
We thank Mr. R. Edwards (Rentokil, England), Drs. N. and G. Koeniger (the Institute for Beekeeping, Federal Republic of Germany), Dr. J. Woyke (University of Warsaw, Poland), Drs. W. Skowronek and M. Biliński (the Beekeeping Institute, Poland), Dr. M. Mardan (Agricultural University of Malaysia), Dr. H. S. Yong (University of Malaya), Dr. P. Akratanakul (Kasetsart University, Thailand), Dr. S. Wangsiri (Chulalongkorn University, Thailand), Dr. I. Okada and M. Ono (Tamagawa University, Japan), Dr. S. Sakai (Daito Bunka University, Japan), Dr. H. Yamamoto (Dokkyo University of Medicine, Japan), Dr. S. Makino (Hokkaido University, Japan), Mr. Shimotori (Shimotori Apiary, Japan), Mr. M. Imanishi (Machida Yohgo School, Japan), and Mr. Aragaki (Aragaki Apiary, Japan) for their kind assistance and advice in collecting the materials.

We also thank Dr. Velthuis (University of Utrecht, the Netherlands) for kindly reading this manuscript and offering valuable comments.

\section{REFERENCES}

Akre, R. D. (1982) Social wasps. In: Social Insects, Vol. 4 (ed.: H. P. Hermann), pp. 1-105. Academic Press, New York.

Crozier, R. H. (1975) Hymenoptera. Animal Cytogenetics, Vol. 3, Insecta \%. Gebruber Borntrager, Berlin and Stuttgart.

GREENE, A. (1979) Behavioral characteristicss as indicators of yellowjacket phylogeny (Hymenoptera: Vespidae). Ann. Entomol. Soc. Amer. 72, 614-619.

HoshibA, H. (1985) The karyological and G-banding analyses of a polistine male wasp, Parapolybia indica saussure (Vespidae, Hymenoptera). Proc. Japan Acad. 61B, 119-120.

Hoshiba, H. and Ono, M. (1984) The early emerging male of the Japanese paper wasp, Polistes snelleni Saussure (Vespidae, Hymenoptera) and its chromosomes. Proc. Japan Acad. 60B, 368371.

Hoshiba, H. and Yамамото, H. (1985) Karyological studies on the three species of the haploid males of Vespinae, Vespa mandarinia Smith, $V$. simillima xanthoptera Cameron and Vespula flaviceps (Smith) (Vespidae, Hymenoptera). Proc. Japan Acad. 61B, 67-70.

Hung, A. C. F., Reed, H. C. and Vinson, S. B. (1981) Chromosomes of four species of Polistes wasps (Hymenoptera: Vespidae). Cariologia 34, 225-230.

IMAI, H. T. (1975) Evidence for non-random localization of the centromere on mmammalian chromosomes. J. theor. Biol. 49, 111-123.

IMAI, H. T. (1978) On the origin of telocentric chromosomes in mammals. J. theor. Biol. 71, 619637.

ImAI, H. T. (1986) Modes of species differentiation and karyotype alteration in ants and mammals. In: Modern aspect of species (ed.: P. H. Raven and W. J. Bock), pp. 87-105. Univ. Tokyo Press, Tokyo.

Imai, H. T., Baroni Urbani, C., Kưota, M., Sharma, G. P., Narasimhanna, M. N., Das, B. C., Sharma, A. K., Sharma, A., Deodikar, G. B., Vaidya, V. G. and RajasekarasetTy, M. R. (1984) Karyological survey of Indian ants. Jpn. J. Genet. 59, 1-32.

ImAI, H. T. and CROZIER, R. H. (1980) Quantitative analysis of directionality in mammalian karyotype evolution. Amer. Natl. 116, 537-569.

ImaI, H. T., CROzIER, R. H. and TAYLOR, R. W. (1977) Karyotype evolution in Australian ants. Chromosoma (Berl.) 59, 341-393.

IMAI, T. H. and MARUYAMA, T. (1978) Karyotype evolution by pericentric inversion as a stochastic process. J. theor. Biol. 70, 253-261.

Imai, T. H., Maruyama, T., Gojobori, T., Inoue, Y. and Crozier, R. H. (1986) Theoretical bases for karyotype evolution. I. The minimum interaction hypothesis. Amer. Natl. 128, 900-920.

Imai, T. H. Takahata, N., Maruyama, T., Daniel, A., Honda, T., Matsuda, Y. and Moriwaki, K. 
(1988b) The theoretical bases for karyotype evolution. II. The fusion burst in man and mouse. Jpn. J. Genet. 63, 313-342.

Imai, H. T., TAYloR, R. W., Crosland, M. W. J. and Crozier, R. H. (1988a) Modes of spontaneous chromosomal mutation and karyotype evolution in ants with reference to the minimum interaction hypothesis. Jpn. J. Genet. 63, 159-185.

IsHIKAWA, R. (1965) Vespidae, Iconographia Insectomum Japonicomum Color Naturali Edida 3: 292. Hokuryukan, Tokyo. (in Japanese)

KERR, W. E. (1952) A variacao do numero de cromosomas na evolucao dos Hymenoptera. Sci. Genet. 4, $182-190$.

MACHIDA, J. (1934) The spermatogenesis of the three species of Polisites. Porc. Imper. Acad. Japan 10, 151-158.

MatsuURA, M and Yamane, Sk. (1984) Comparative ethology of the Vespine Wasps, pp. 428. Hokkaido Univ. Press, Sapporo.

NAITo, T. (1978a) Chromosomes of the Tenthredo olivaceamesomelas group (Hymenoptera, Tenthredinidae). Kontya (Tokyo) 46, 257-263.

NAITo, T. (1978b) Chromosomes of the genus Macrophya Dahlbom (Hymenoptera, Tenthredinidae). Kontyû (Tokyo) 46, 470-479.

NAITo, T. (1982) Chromosome number differentiation in sawflies and its systematic implication (Hymenoptera, Tenthredinidae). Kontyu (Tokyo) 50, 569-587.

PARDI, L. (1947) Richerche sui Polistini. VII. La spermatogenesi di Polistes galicus (L.) e di Polistes (Leptopolistes) omissus (Weyrauch). Sci. Genet. 3, 14-22.

Pompolo, S. G. and TAKahasi, C. S. (1986) Karyotype of two species of wasps of the genus Polistes (Polistinae, Vespidae, Hymenoptera). Insectes Sociaux (Paris) 33, 142-148.

YAMANE, S. (1969) Preliminary observations on the life history of two polistine wasps, Polistes snelleni and P. biglumis in Sapporo, northern Japan. J. Fac. Sci. Hokkaido Univ. (VI. Zool.) $17,78-105$.

YAMANE, Sk. (1976) Morphological and taxonomic studies on vespine larvae, with reference to the phylogeny of the subfamily Vaspinae (Hymenoptera: Vespidae). Ins. Matsum. N. S. 8, 1-45.

YAMANE, Sk. and YAMANE, S. (1978) A new species and synonymy in the subgenus Polistes of

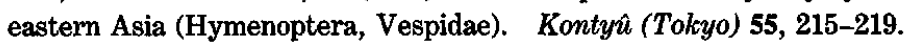

